\title{
Chapter 5 \\ Economic and Political Networks and Firm Openness: Evidence from Indonesia
}

\author{
Yasuyuki Todo and Daichi Shimamoto
}

Economic growth of emerging economies often relies on learning of the knowledge and technology of developed countries and their diffusion within the economy. In both cases, social and economic networks play an important role, and the structure of such networks substantially influences their effects on growth.

On the one hand, learning of foreign knowledge and technology can be promoted by ties with foreign partners through international trade and investment (Keller 2004). In emerging economies such as China and Indonesia, a number of firm-level studies have empirically found evidence of learning by exporting and knowledge spillovers from foreign direct investment (Arnold and Javorcik 2005; Blalock and Gertler 2004, 2008; Todo and Miyamoto 2006; Todo et al. 2011). In social network studies, researchers often argue that ties with outsiders facilitate the diffusion of useful knowledge (Granovetter 1973, 2005; Burt 1992, 2004).

On the other hand, knowledge diffusion within an economy can be promoted by dense social networks, particularly, social capital, or social networks in which actors are strongly and densely connected through trust, because trust is required in

This research was conducted as part of a project entitled 'Empirical Analysis on Determinants and Impacts of Formation of Firm Networks,' undertaken at the Research Institute of Economy, Trade, and Industry (RIETI). The authors would like to thank JSPS Kakenhi Grant (No. 25101003 and 26245037) for financial supports and Kanchan Chandra, Masahisa Fujita, Patarapong Intarakumnerd, Masayuki Morikawa, Tetsuji Okazaki, Osamu Saito, Ryuhei Wakasugi, Roy Bin Wong, Chikako Yamauchi, and seminar participants at RIETI and the Graduate Institute for Policy Studies for their helpful comments. The opinions expressed and arguments employed in this paper are the sole responsibility of the authors and do not necessarily reflect those of RIETI, Waseda University, or any institution with which the authors are affiliated. JEL classifications of this work are D22, F14, F23.

\author{
Y. Todo $(\bowtie)$ \\ Faculty of Political Science and Economics, Waseda University, Tokyo, Japan \\ e-mail: yastodo@waseda.jp \\ D. Shimamoto \\ Faculty of Economics, Kindai University, Higashiosaka, Japan \\ (C) The Author(s) 2019 \\ K. Tsunekawa and Y. Todo (eds.), Emerging States at Crossroads, \\ Emerging-Economy State and International Policy Studies, \\ https://doi.org/10.1007/978-981-13-2859-6_5
}


transactions of knowledge due to information asymmetry (Durlauf and Fafchamps 2005). Empirical studies have found that social capital is positively correlated with income and productivity at the country level (Knack and Keefer 1997), the subnational region level (Gennaioli et al. 2013), the firm level (Phelps 2010), and the individual level (Rost 2011).

However, strong ties with trust may not always be effective in knowledge diffusion or productivity enhancement. Granovetter (1973) and Burt (1992, 2004) show that weak ties with outsiders are more effective because the knowledge of actors who are densely connected largely overlaps. Todo et al. (2016) reveal that the performance of a firm is lower when its network partners are densely connected.

Moreover, some studies emphasize the dark side of social capital. Olson (1984) argues that social capital in lobbying groups is often intensified in order to receive rents from the government, leading to protectionist policies and, thus, to economic stagnation. Some empirical studies indeed show negative effects of strong ties on economic and social development (Satyanath et al. 2013; Beugelsdijk and Smulders 2004).

However, empirical studies have not fully investigated the detailed mechanism of the argument by Olson (1984) from the political economy perspective. To fill the gap, this paper examines how social capital generated from economic rents is intensified and leads to the protectionism of economic actors, taking firm managers' views of globalization in Indonesia as an example. We hypothesize that firms' political networks created to receive rents strengthen trust toward domestic citizens and business networks with domestic firms, in turn weakening trust toward foreign citizens and networks with foreign firms. Trust and networks within the country reinforce each other through dense communication but deteriorate trust and networks across countries because trust toward insiders and trust toward outsiders often substitute, rather than complement, each other (Ermisch and Gambetta 2010). Then, trust and networks within the country, combined with the lack of trust and networks across countries, enhance protectionism. This can be a source of middle-income traps for emerging economies. Figure 5.1 summarizes this mechanism.

We test these hypotheses using firm-level data collected by the authors in the manufacturing sector in a major emerging economy, Indonesia. Indonesia is a suitable target for this research because the political ties of firms play an important role in business. According to the OECD (2012), 26\% of firms in Indonesia expect to give gifts to obtain an operating license from the government. This figure is substantially higher than those for the Philippines $(6.6 \%)$ and Vietnam $(6.7 \%)$, indicating the particular significance of political ties in economic activities in Indonesia. Our data are unique in that they include information on each firm's business and political networks, firm managers' views of globalization, such as the foreign ownership of private firms and free trade agreements (FTAs), and the level of these managers' trust toward domestic and foreign citizens.

Our empirical results support most of our hypotheses. Managers of firms that possess networks with the government to earn rents are more likely to oppose the foreign ownership of firms and FTAs through enhancing trust and networks within the country and deteriorating those across countries. Assuming 


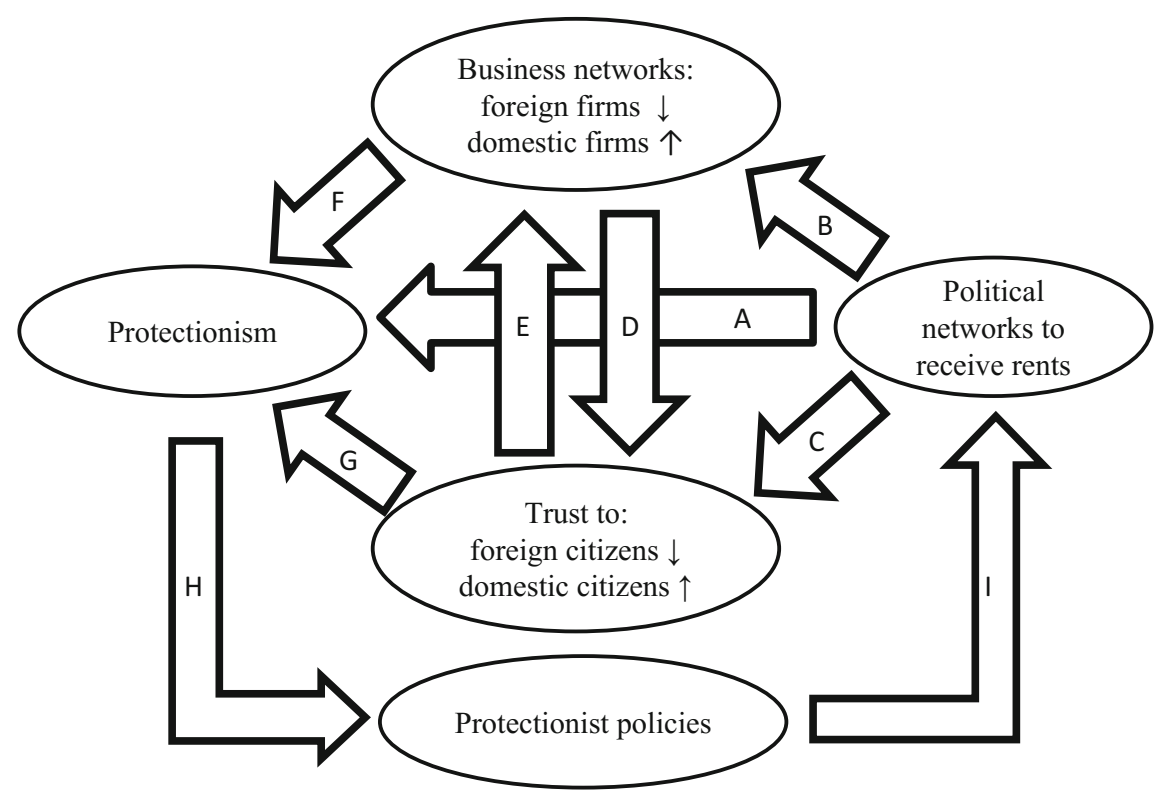

Fig. 5.1 Linkages between protectionism, business and political networks, and trust. Source Constructed by the author

that protectionism of the public leads to the actual implementation of protectionist policies (although this paper did not examine this assumption), our results suggest a vicious cycle between political networks associated with rents and the protectionism of economic actors. Once the vicious cycle is initiated, it may be difficult to escape because political ties and protectionism intensify each other. Because many studies empirically show the benefits of globalization (see Sect. 2.1 for details), this vicious cycle results in economic stagnation. This mechanism may be able to explain middle-income traps in which the income of middle-income countries stagnates for a long time and cannot reach the level of current developed countries.

Some studies, including Tomiura et al. (2013) and Naoi and Kume (2011), have used individual-level data to examine how protectionist views of globalization are determined. For example, Naoi and Kume (2011) find that Japanese are more likely to support agricultural protectionism if they feel that their jobs are insecure or they have family members or relatives who engage in farming. Tomiura et al. (2013) show evidence that wealthy citizens or those in managerial positions are more supportive of trade liberalization, whereas citizens engaging in agriculture support liberalization less. However, they did not incorporate into their analysis the effects of business or political networks or the level of trust toward domestic and foreign citizens. Incorporating these issues is the contribution of this paper. 


\title{
5.1 Hypotheses and Estimation Methods
}

\subsubsection{Benefits of Globalization}

Economic integration and globalization provide many benefits to the local economy. For example, many studies have found evidence of learning by exporting, i.e., productivity growth from exporting. Blalock and Gertler (2004) find that when Indonesian firms began to export, their productivity increased by 2-5\%. A meta-analysis by Martins and Yang (2009) confirms the positive learning-by-exporting effect, revealing a larger effect for less developed countries, including emerging countries. In addition to its effect on productivity in production activities, exporting is shown to raise productivity in innovative activities in Spain, a developed country that is not in the technology frontier (Salomon and Shaver 2005). The import of intermediate and final goods is also beneficial to local firms, as Amiti and Konings (2007) find using firm-level data from Indonesia.

Inflows of foreign direct investment (FDI) are also found to promote productivity growth in the host country. Using establishment-level data from Indonesia, Arnold and Javorcik (2005) find that domestic firms improve their productivity when they are acquired by foreign firms. FDI can even benefit other domestically owned firms in the host country through knowledge spillovers. For Indonesia, Takii (2005) finds positive spillovers from FDI. Spillovers are more significant when FDI is associated with local research and development (R\&D) activities in the host country (Todo and Miyamoto 2006) and when foreign-owned firms are vertically integrated with, i.e., procure supplies from, local firms (Javorcik 2004). Using cross-country panel data for less developed countries, Borensztein et al. (1998) find that FDI has a positive effect on growth in GDP per capita when the education level is sufficiently high.

\subsubsection{Linkages Between Protectionism, Business and Political Networks, and Trust}

\begin{abstract}
Although these benefits of globalization for the local economy have been found in academic research, some people, including firm managers, have a negative view of globalization. Such protectionism may be generated by a lack of overseas business networks and by distrust toward foreign citizens; these two factors are interlinked with each other and affected by political ties, as explained in detail below and summarized in Fig. 5.1.

We hypothesize that an important source of protectionist views of globalization is firms' ties with politicians and the government to receive economic rents. Firms with strong political networks are more likely to perceive foreign-owned firms as threats and oppose the penetration of FDI that may deteriorate their rents (arrow A in Fig. 5.1). In addition, politically connected firms are more willing to expand transactions in the domestic market regulated by the government-because their
\end{abstract}


rents are earned domestically_ - and are less willing to create business networks with foreign firms (arrow B). For the same reason, managers of firms with close political ties tend to distrust foreigners because foreigners are often eager to destroy their rents (arrow C).

Trust and business networks within a country reinforce each other, and those across countries intensify each other. Managers with fewer business ties with foreign firms are less likely to trust foreign citizens simply due to a lack of direct communication (arrow D). In turn, distrust toward foreigners discourages firms' overseas activities (arrow E).

Finally, when firm managers have little interaction with foreign firms, they cannot realize the benefits of globalization and thus may not support globalization (arrow $\mathrm{F}$ of Fig. 5.1). Furthermore, managers who distrust foreign citizens are more likely to perceive foreign-owned firms and foreign citizens as threats rather than as collaborative partners that bring new knowledge (arrow G), as Fafchamps (2006) suggests. Accordingly, political networks affect protectionist views of globalization directly and indirectly through trust and business networks.

\subsubsection{Estimation Method}

To test these hypotheses, we estimate the following equations for firm $i$ and its owner or highly ranked manager:

$$
\begin{gathered}
\text { VIEW }=\beta_{0}^{G}+\beta_{1}^{G} N E T W O R K_{i}+\beta_{2}^{G} T R U S T_{i}+\beta_{3}^{G} P O L_{i}+\beta_{4}^{G} X_{i}+\beta_{5}^{G} D_{i}+\varepsilon_{i}^{G}, \\
N E T W O R K_{i}=\beta_{0}^{N}+\beta_{1}^{N} T R U S T_{i}+\beta_{2}^{N} P O L_{i}+\beta_{3}^{N} X_{i}+\beta_{4}^{N} D_{i}+\varepsilon_{i}^{N}, \\
\text { TRUST } T_{i}=\beta_{0}^{T}+\beta_{1}^{T} N E T W O R K_{i}+\beta_{2}^{T} P O L_{i}+\beta_{3}^{T} X_{i}+\beta_{4}^{T} D_{i}+\varepsilon_{i}^{T} .
\end{gathered}
$$

VIEW is a measure of the manager's positive views of globalization. NETWORK is a vector of measures of the firm's ties with domestic firms and those with foreign firms. Similarly, TRUST is a vector of measures of the manager's trust toward domestic and foreign citizens. $P O L$ is a measure of the firm's ties with politicians and the government. $X$ is a vector of control variables at the firm and manager levels, $D$ is a vector of industry dummies, and $\varepsilon$ is the error term. The next section will explain in detail how we construct these variables.

Based on the argument in the previous subsection, we hypothesize that networks with foreign firms and trust toward foreign citizens have a positive effect on the proglobalization views of managers, whereas networks with domestic firms, trust toward domestic citizens, and networks with politicians have a negative effect. Business networks with foreign firms and trust toward foreign citizens have a positive effect on each other, whereas they are negatively affected by political ties. Conversely, networks with domestic firms and trust toward domestic citizens have a positive effect on each other, whereas they are positively affected by political ties.

Equations (5.1)-(5.3) should be estimated jointly, for example, using two-stage least squares estimations, to identify interlinked causal relations between views of 
globalization, business and political networks, and trust. However, because we do not have a good instrument for such joint estimation, we estimate each equation separately using an ordered logit estimation when the dependent variable is a categorical variable and a Tobit estimation when it is continuous with a lower limit of zero. Because this study examines the correlation between the variables of interest, rather than their causal relations, the results should be viewed with caution.

\subsection{Data}

\subsubsection{Survey}

The analysis in this study is based on data from an establishment-level survey conducted by the authors in cooperation with the Institute for Economic and Social Research (LPEM), Faculty of Economics, University of Indonesia. The survey was conducted in seventeen cities in six provinces ${ }^{1}$ in Indonesia from September 21, 2014 to December 7, 2014 and covered five manufacturing industries, i.e., the textile, chemical, metal and machinery, electrical and electric machinery, and transportation equipment industries. The five industries were selected because these are the major manufacturing industries in Indonesia. The seventeen cities were chosen because the number of establishments in the five industries in each city exceeded a threshold level, according to the Manufacturing Industry Directory of the Central Bureau of Statistics (BPS) for 2012 (hereafter, the 2012 Directory).

Among the establishments, $40 \%$ are in the textile industry, $32 \%$ are in the chemical industry, $18 \%$ are in the metal and machinery industry, $5 \%$ are in the electricity and electric machinery industry, and $5 \%$ are in the transport equipment industry. The size of the surveyed firms varies: $11 \%$ are small firms with fewer than thirty workers, $30 \%$ are medium-sized firms with fewer than one hundred workers, and $58 \%$ are large firms with one hundred or more workers.

In the survey, we randomly selected establishments from the 2012 Directory and conducted a face-to-face interview with each establishment. The 2012 Directory covers all establishments with thirty workers or more and randomly selected establishments with fewer workers. When any selected firm refused to respond or no longer existed, we replaced it with a randomly selected firm. In three cities, Pekalongan, Medan, and Semarang, after some refusals, no more establishments were available in the 2012 Directory because there were few establishments in these cities. Therefore, we randomly selected establishments for replacement from the Directory for 2011. Although our initial target was 400 establishments, we collected data from only 332 firms due to time constraints.

\footnotetext{
${ }^{1}$ These are Cilegon and Tangerang in Banten Province, Jakarta Barat, Jakarta Pusat, Jakarta Selatan, Jakarta Timur, and Jakarta Utara in DKI Jakarta, Semarang and Pekalongan in Central Java Province, Surabaya in East Java Province, Medan in North Sumatera Province, and Bandung, Bekasi, Bogor, Cimahi, Depok, and Taskmalaya in West Java Province.
} 
Table 5.1 Types of respondents

\begin{tabular}{l|c|c}
\hline $\begin{array}{l}\text { Types of } \\
\text { respondents }\end{array}$ & Number of firms & Percentage \\
\hline Director & 47 & 14.2 \\
\hline Owner & 52 & 15.7 \\
\hline Managers & 110 & 33.1 \\
\hline Others & 115 & 34.6 \\
\hline Missing & 8 & 2.4 \\
\hline Total & 332 & 100.0 \\
\hline
\end{tabular}

Note Directors include vice presidents, accounting directors, finance directors, managing directors, legal directors, and other positions titled as directors

The questions in the survey consist primarily of two parts. The first part contains questions about standard characteristics of establishments, such as sales, the value of capital stocks, the number of full-time workers, ownership, and board members. This part also includes questions about the firm's business networks, including the number of buyers and suppliers of each establishment by location and ownership.

The second contains questions directed toward establishments' highly ranked managers. Our target was the top manager, such as the president or CEO, but when he/she was not available, we asked a procurement or accounting manager or any highly ranked manager. Table 5.1 shows the composition of respondents by position. Company executives accounted for $14.2 \%$, owners $15.7 \%$, highly ranked managers $31.1 \%$, and other positions $34.6 \%$. Questions to managers were related to their ethnicity, religion, education background, participation in associations, and personal ties with politicians. We also asked the managers to what degree they trusted particular types of people, such as politicians, Indonesians, and foreigners. In addition, we surveyed managers' views of globalization, asking them whether they thought that the foreign ownership of private firms should be limited in Indonesia and that free trade agreements are beneficial to small and medium-sized enterprises in Indonesia.

Some firms did not answer all questions. Therefore, our estimation utilizes a sub-sample of 276 firms for which all necessary variables are available.

\subsubsection{Variables}

From the data collected through the survey, we construct key variables in this paper related to business and political ties and managers' views of globalization. First, to measure the business networks of establishments, we create two variables: the number of domestically located buyers and suppliers and the number of overseas buyers and suppliers. The number of domestic transaction partners represents the strength of domestic business ties, whereas the number of overseas partners represents the strength of ties across countries. To incorporate a nonlinear relationship between 
these business network variables and others, we take a log of the two after adding one. Therefore, the lower limit of the two variables is zero.

Second, we construct a dummy variable to indicate whether firms have a connection with any politician or the government that provides economic rents to firms based on the following question to managers: "Do you feel that you are able to obtain government approvals more easily than other companies?" We define the dummy variable for political ties as one if the response of managers is yes. Alternatively, for political ties in a broader context, we construct a dummy variable that takes a value of one if firms can receive valuable information from the government, receive any subsidy from the government, or have politicians on their boards of directors or if their managers have any personal relationships with politicians.

Third, to measure the respondent manager's views of globalization, we construct two measures from the survey questions. In the survey, we asked respondent managers whether they agreed with the statement, "In general, the government should limit the foreign ownership of domestic companies." We define a categorical variable for supporting the foreign ownership of private firms as four if the respondent's reply to the question was "completely disagree," three if it was "somewhat disagree," two if it was "somewhat agree," and one if it was "completely agree."

Another measure of managers' view of globalization is based on their responses to the statement, "FTAs are beneficial to small and medium-sized enterprises (SMEs) in Indonesia." We define a categorical variable for positive views of globalization from one to four, for which four indicates strong agreement with the statement.

Fourth, we measure the degree of trust toward domestic and foreign citizens based on survey questions to managers. We define a categorical variable for trusting foreign citizens as one if managers responded, "I do not trust foreigners at all," two, "I do not trust foreigners very much," three, "I trust foreigners to some extent," and four, "I trust foreigners completely." Similarly, we define a categorical variable for trusting domestic citizens. In this study, we assume that the degree of managers' trust toward domestic citizens indicates the strength of domestic personal ties, whereas the degree of managers' trust toward foreign citizens indicates the strength of foreign personal ties.

We utilize a set of control variables at the firm and managerial levels. Firmlevel variables include the log of the number of permanent workers, firm age and firm age squared, and the foreign ownership ratio. As Melitz (2003) argues, business networks, particularly overseas business networks, are determined by the productivity of firms. However, if we included productivity measures, such as sales per worker, we would lose many firms from the sample because many firms did not report sales. Therefore, we did not include any direct productivity measure, assuming that firm size is correlated with the productivity level. In empirical studies on the determinants of exports and firm size is found to be a better predictor than productivity (Todo 2011).

Manager-level variables are age and age squared, the log of years of education, a male dummy, the degree of trust toward politicians, a dummy variable that indicates whether the manager belongs to any association, such as alumni, business, or recreational associations, and religion and ethnicity dummies. These individual characteristics are found to determine the level of trust toward people in general in 
Table 5.2 Managers' views of globalization

\begin{tabular}{l|l|l|l|l|l|l}
\hline Variables & Description & 1 & 2 & 3 & 4 & Mean \\
\cline { 2 - 7 } & $\begin{array}{l}\text { Strongly } \\
\text { disagree } \\
(\%)\end{array}$ & $\begin{array}{l}\text { Disagree } \\
(\%)\end{array}$ & Agree (\%) & $\begin{array}{l}\text { Strongly } \\
\text { agree (\%) }\end{array}$ & \\
\hline VIEW_FDI & $\begin{array}{l}\text { Foreign } \\
\text { ownership } \\
\text { should be } \\
\text { liberalized }\end{array}$ & 27.0 & 60.7 & 11.2 & 1.1 & 1.87 \\
\hline VIEW_FTA & $\begin{array}{l}\text { FTAs are } \\
\text { beneficial } \\
\text { to SMEs }\end{array}$ & 4.5 & 29.2 & 53.6 & 12.7 & 2.75 \\
\hline
\end{tabular}

Table 5.3 Levels of trust toward Indonesians and foreigners

\begin{tabular}{l|l|l|l|l|l|l}
\hline Variables & Description & 1 & 2 & 3 & 4 & Mean \\
\cline { 3 - 6 } & $\begin{array}{l}\text { Do not } \\
\text { trust at all } \\
(\%)\end{array}$ & $\begin{array}{l}\text { Do not } \\
\text { trust (\%) }\end{array}$ & Trust (\%) & $\begin{array}{l}\text { Trust very } \\
\text { much (\%) }\end{array}$ & \\
\hline TRUST_IND & $\begin{array}{l}\text { Trust } \\
\text { toward } \\
\text { Indonesians }\end{array}$ & 0.4 & 7.1 & 79.8 & 12.7 & 3.05 \\
\hline TRUST_FOR & $\begin{array}{l}\text { Trust } \\
\text { toward } \\
\text { foreigners }\end{array}$ & 2.6 & 21.4 & 70.0 & 6.0 & 2.79 \\
\hline
\end{tabular}

existing studies, such as those by Alesina and La Ferrara (2002), Algan and Cahuc (2014), and Nunn and Wantchekon (2011).

\subsubsection{Summary Statistics}

Table 5.2 shows the distribution of the two measures of managers' view of globalization: $27 \%$ strongly oppose foreign ownership liberalization, $61 \%$ oppose it to some extent, $11 \%$ support it to some extent, and only $1 \%$ support it strongly. To the statement that FTAs are beneficial to SMEs, 29\% disagree to some extent, and 54\% agree to some extent.

As shown in Table 5.3, the level of managers' trust toward Indonesians is high: only $7.5 \%$ do not trust Indonesians to any extent, whereas 80 and $13 \%$ trust them to some extent and completely, respectively. However, the level of trust toward foreigners is lower: $24 \%$ of managers do not trust foreigners to some extent or completely.

The number of transaction partners, i.e., buyers and suppliers, reported by firms is not large for many firms (Table 5.4). The median number of transaction partners in Indonesia is 5, whereas the number of overseas partners is zero for $19 \%$ of firms. 
Table 5.4 Number of transaction partners in Indonesia and foreign countries

\begin{tabular}{l|l|l|l|l|l|l|l}
\hline Variables & Description & Min. & $10 \%$ & $50 \%$ & $90 \%$ & Max & Mean \\
\hline NET_IND & $\begin{array}{l}\text { Number of } \\
\text { transaction } \\
\text { partners in } \\
\text { Indonesia }\end{array}$ & 0 & 0 & 5 & 17 & 598 & 11.6 \\
\hline NET_FOR & $\begin{array}{l}\text { Number of } \\
\text { overseas } \\
\text { transaction } \\
\text { partners }\end{array}$ & 0 & 0 & 0 & 2 & 54 & 0.87 \\
\hline
\end{tabular}

Summary statistics for other firm- and manager-level variables are provided in Table 5.5. Of the firms, 5.6\% recognize that they can receive business approvals from the government more easily than other firms $(\mathrm{POL}=1)$. The dummy variable for political ties in a broader context (POL_BROAD) is one for 13.5\% of firms. The average and median numbers of permanent workers are 257 and 100, respectively. On average, the managers are 45.2 years old, with 14.7 years of education; $76 \%$ of managers are male; and $47 \%$ of managers belong to an association.

\subsection{Estimation Results}

\subsubsection{Benchmark Results}

The results from the estimation of Eq. (5.1), using an ordered logit model, are shown in columns (1) and (2) of Table 5.6. The results in column (1) indicate that a firm manager is more likely to support the limitations of foreign ownership of private firms in Indonesia when the firm transacts with more local buyers and suppliers. In column (2), we find that higher trust toward foreign citizens is correlated with a higher propensity for managers to recognize the benefits of FTAs to Indonesia. These findings imply that strong ties with domestic firms are associated with negative views of globalization, whereas trust toward foreign citizens is associated with positive views. Contrary to this theoretical prediction, political ties are not directly correlated with protectionist views.

Next, columns (3) and (4) of Table 5.6 present the results from an ordered logit estimation of Eq. (5.2). We find that strong ties between politicians and the government are correlated negatively with the level of managers' trust toward foreigners and positively with the level of their trust toward Indonesians. Trust toward Indonesians is also negatively correlated with the number of overseas business partners.

Finally, we present results from the Tobit estimation of Eq. (5.3) in columns (5) and (6) of Table 5.6, finding that Indonesian firms are more likely to transact with 
Table 5.5 Summary statistics of key variables

\begin{tabular}{|c|c|c|c|c|c|c|}
\hline Variables & Description & Mean & S.D. & Min & Median & Max \\
\hline \multicolumn{7}{|l|}{ Firm level } \\
\hline POL & $\begin{array}{l}\text { Dummy for } \\
\text { political ties }\end{array}$ & 0.056 & 0.231 & 0 & 0 & 1 \\
\hline POL_BROAD & $\begin{array}{l}\text { Dummy for } \\
\text { broader } \\
\text { political ties }\end{array}$ & 0.135 & 0.342 & 0 & 0 & 1 \\
\hline $\mathrm{L}$ & $\begin{array}{l}\text { Number of } \\
\text { permanent } \\
\text { workers }\end{array}$ & 256.640 & 532.648 & 0 & 100 & 6570 \\
\hline F_AGE & Firm age & 26.865 & 13.637 & 1 & 25 & 98 \\
\hline FShare & $\begin{array}{l}\text { Foreign } \\
\text { ownership } \\
\text { ratio }\end{array}$ & 12.833 & 29.194 & 0 & 0 & 100 \\
\hline \multicolumn{7}{|l|}{ Manager level } \\
\hline AGE & Age & 45.176 & 11.302 & 20 & 45 & 84 \\
\hline EDUC & $\begin{array}{l}\text { Years of } \\
\text { education }\end{array}$ & 14.659 & 3.229 & 1 & 16 & 26 \\
\hline $\operatorname{lnEDUC}$ & $\begin{array}{l}\text { Log of } \\
\text { EDUC }\end{array}$ & 2.650 & 0.304 & 0 & 2.773 & 3.258 \\
\hline MALE & $\begin{array}{l}\text { Male } \\
\text { dummy }\end{array}$ & 0.757 & 0.430 & 0 & 1 & 1 \\
\hline ASSOC & $\begin{array}{l}\text { Dummy for } \\
\text { participa- } \\
\text { tion in } \\
\text { associations }\end{array}$ & 0.446 & 0.498 & 0 & 0 & 1 \\
\hline TRUST_POL & $\begin{array}{l}\text { Level of } \\
\text { trust toward } \\
\text { politicians }\end{array}$ & 2.464 & 0.727 & 1 & 3 & 4 \\
\hline
\end{tabular}

overseas firms when managers of firms trust foreigners more and Indonesians less. Moreover, firms with strong political ties transact with more local firms.

The results from columns (3)-(6) suggest that managers of firms with strong political ties that generate economic rents to their firms trust Indonesians more and foreigners less to avoid competition with foreigners and to maintain their rents, expanding transactions with local firms. In addition, it is suggested that trust toward foreigners promotes transactions with foreign firms and that in turn, transactions with foreign firms promote trust toward foreigners through face-to-face communication with foreigners in these transactions. Conversely, a high level of trust toward Indonesians seems to discourage transactions with foreign firms, likely because it promotes closed networks within the country. 


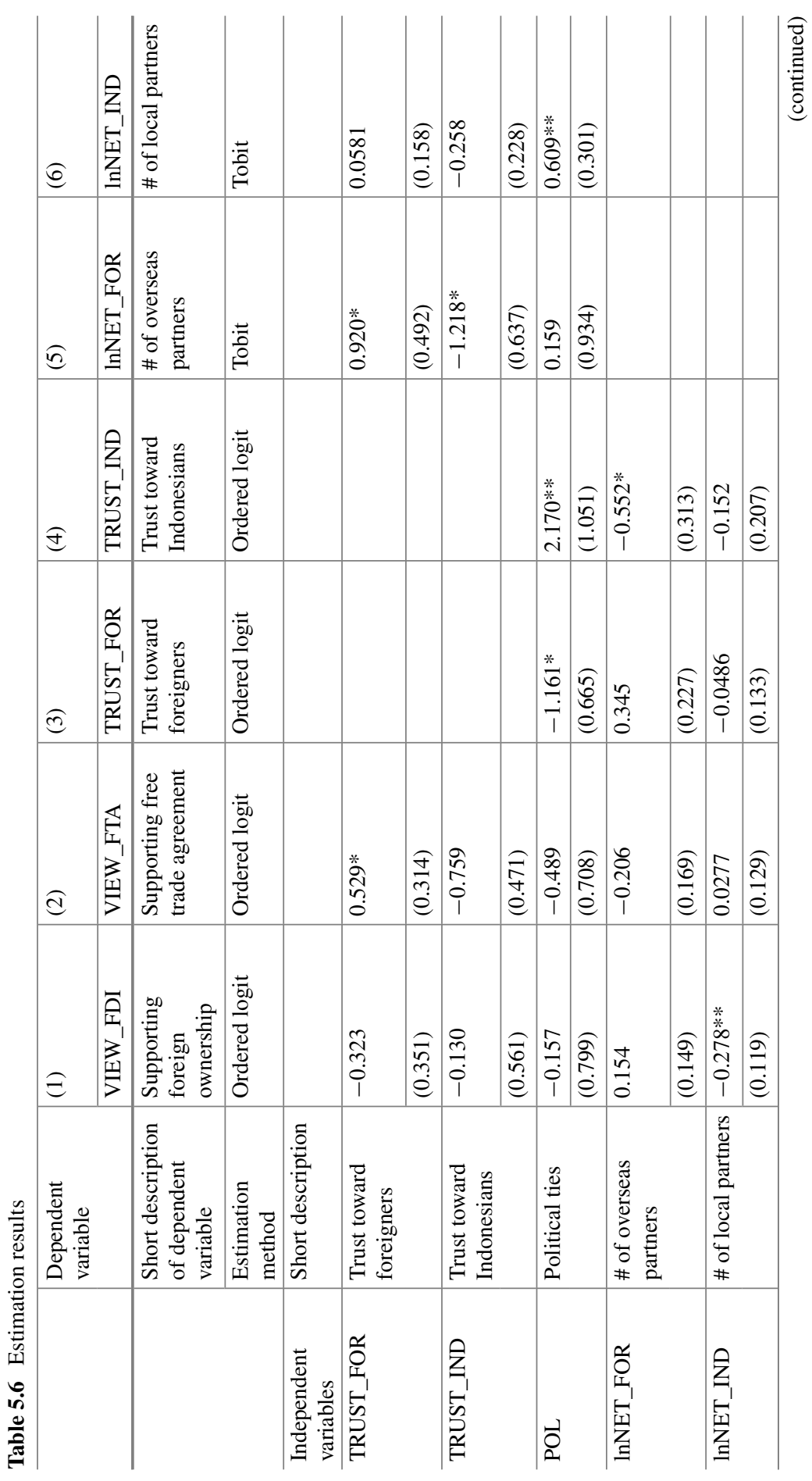




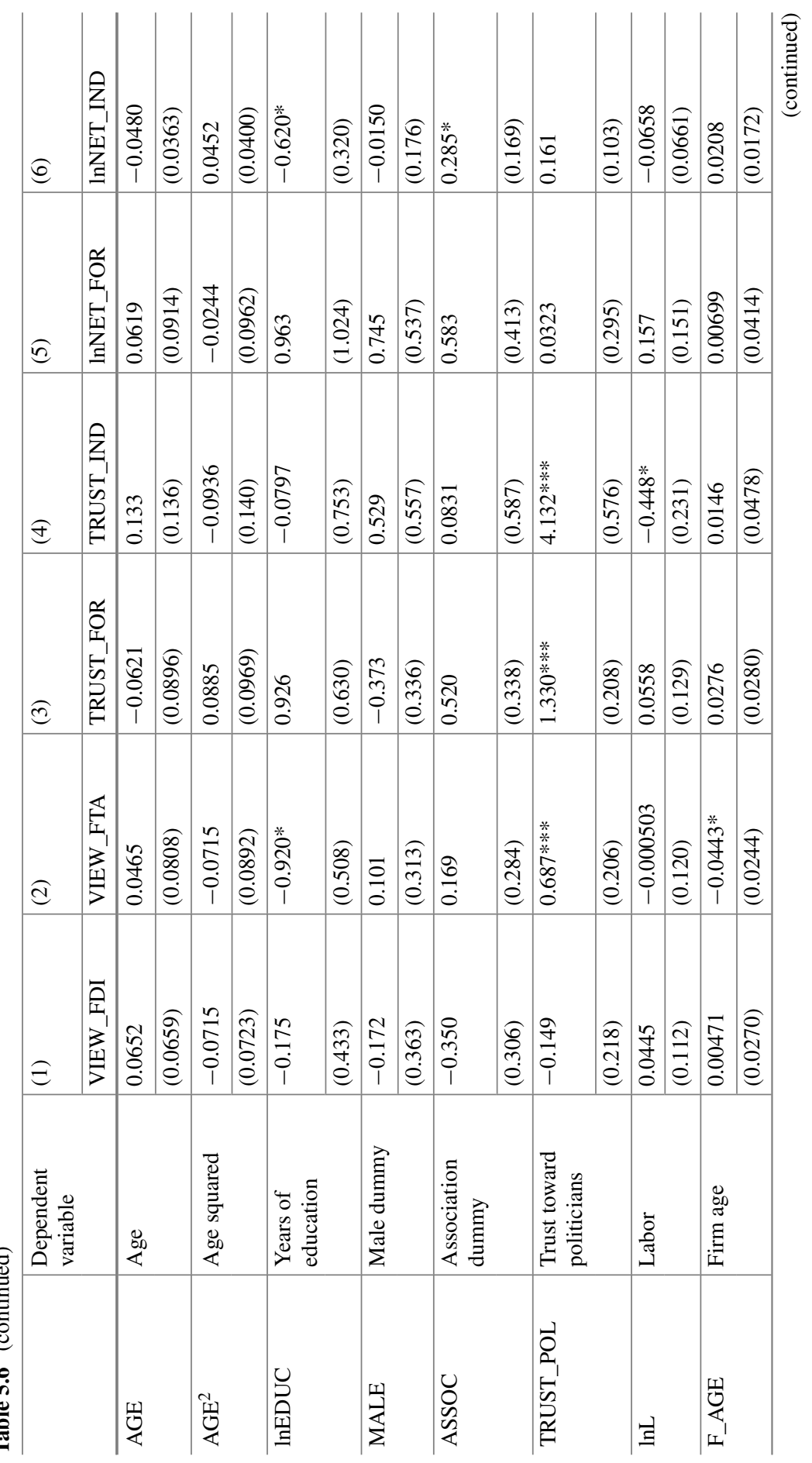




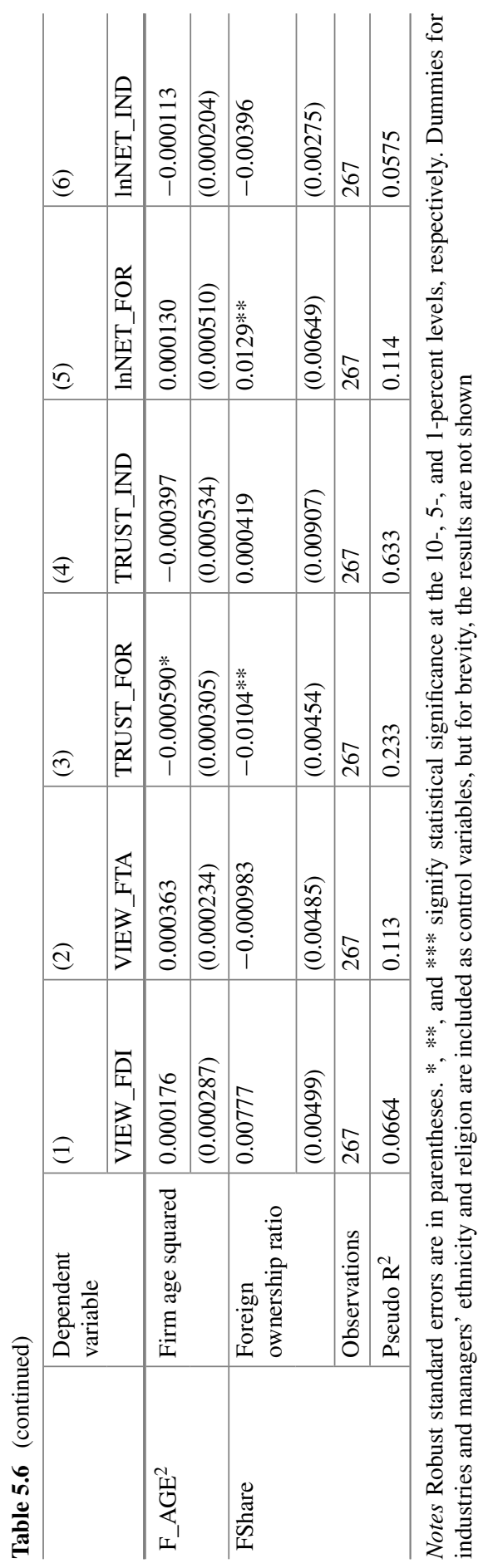




\subsubsection{Alternative Measure of Political Ties}

To check the robustness of the results, we repeat the same regressions using an alternative measure of political ties. As explained in detail in Sect. 5.3, this alternative measure of political ties includes broader aspects of political ties, e.g., having politicians on the board of directors and managers' personal relations with politicians, than the measure based on receiving government approvals more easily that was used in the benchmark results.

The results shown in Table 5.7 are not very different from the benchmark results in Table 5.6. However, the coefficients of the measure of political ties are often smaller and less significant here than in the benchmark results. This implies that the narrower definition of political ties explains the empirical model better, likely because firms' ability to obtain business approvals from the government, which is directly related to rents, is the most important aspect of political ties.

\subsubsection{Discussion}

The results above mostly support the hypotheses explained in Sect. 5.2 and summarized in Fig. 5.1, although some of the predicted links are found in the estimations to be insignificant. In summary, firms' strong ties with politicians that enable firms to receive rents from the government lead to more transactions with domestic firms and higher trust toward domestic people but fewer transactions with foreign firms and lower trust toward foreigners. Trust toward domestic (foreign) citizens and transactions with domestic (foreign) firms reinforce each other and promote negative (positive) views of globalization.

These results suggest that when firms' political ties are strengthened, firms are less likely to be interested in foreign economies and engage in cross-border economic activities, such as international trade and cross-border inward mergers and acquisitions (M\&As). As a result, domestic actors, including firm managers, perceive foreign firms and foreigners as threats.

Then, a democratic government, such as that of Indonesia and many other emerging countries, is likely to implement protectionist policies against globalization, such as limiting the foreign ownership of firms in the country and protecting domestic industries by restricting international trade. Because these regulations consequently provide more rents to domestic firms, political ties between firms and the government are strengthened to receive benefits from rents. This paper did not examine the link between domestic citizens' protectionist views of globalization and the implementation of protectionist policies of the government or between protective policies and political ties. However, if these links exist in practice, there will be a vicious cycle between political ties, protectionist views and policies against globalization.

As shown by many studies, including some for Indonesia, international trade and FDI inflows are sources of growth of domestic productivity through 


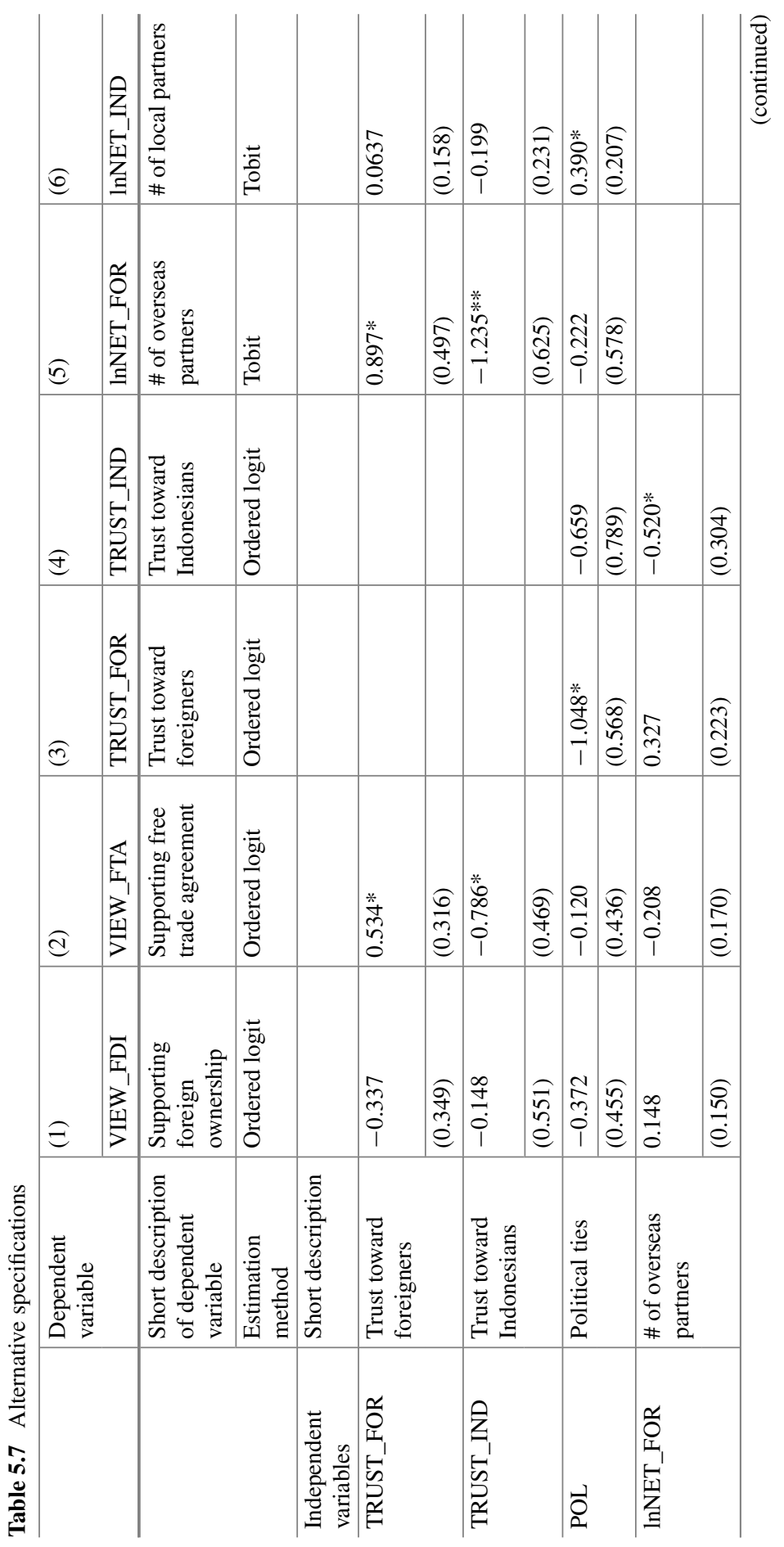




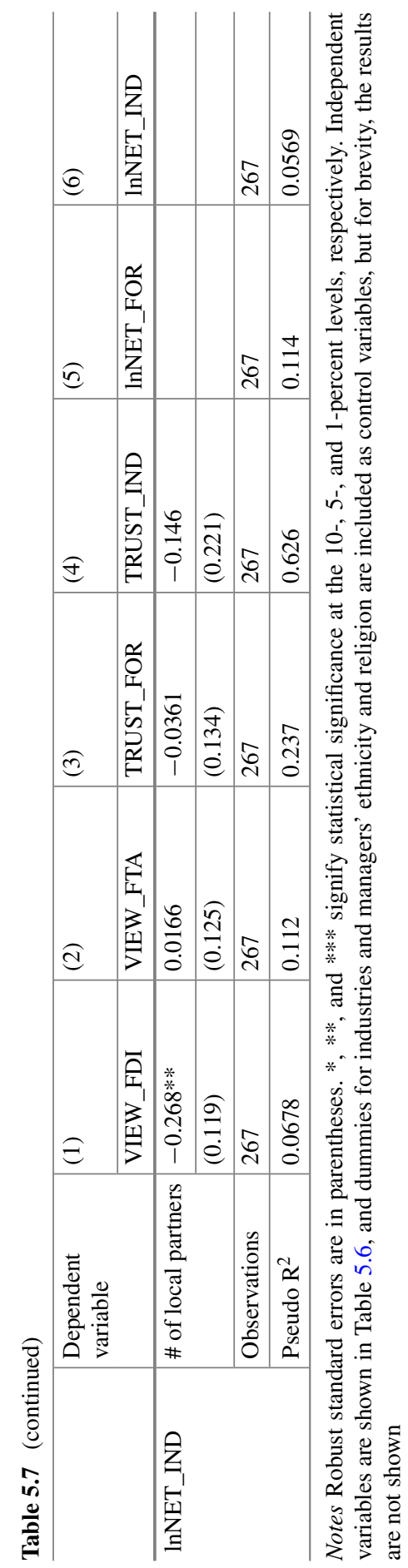


knowledge spillovers (Sect. 2.1). Therefore, this vicious cycle deteriorates openness to the world economy and leads to the stagnation of the domestic economy. In emerging economies such as that of Indonesia, this mechanism may cause middleincome traps. In fact, in many Latin American countries, the income level stagnated for several decades after protectionist policies were implemented in the 1950s. These prolonged middle-income traps may be explained by the vicious cycle between political ties, protectionist views and policies against globalization.

\subsection{Conclusion}

Using a firm-level dataset from the manufacturing sector in Indonesia collected by the authors, we examine the relations between firm managers' protectionist views of globalization and trust toward domestic and foreign citizens and firms' domestic and overseas business networks and ties with the government.

Our data are unique in that they include comprehensive information on various types of political and business economic ties. First, we identify the political ties of each firm based on whether the firm can obtain business approvals from the government more easily than other firms. Second, our data include information about buyers and suppliers of each firm and their location and ownership so that we can identify its business networks with domestic and foreign firms. Finally, our data measure managers' views of globalization, such as the foreign ownership of firms and FTAs.

We find that strong political ties of firms are associated positively with managers' level of trust toward Indonesians and the number of buyers and suppliers in Indonesia and negatively with their level of trust toward foreign citizens. Managers' trust toward foreign citizens and firms' transactions with foreign firms are positively correlated with each other. Trust and business networks within Indonesia are also correlated. Then, when managers trust Indonesians more or firms transact with more domestic firms, managers are more likely to have a protectionist view of globalization.

The results suggest a vicious cycle between the political ties between local firms and the government and views and policies against globalization, which leads to economic stagnation due to a lack of knowledge diffusion from abroad. This mechanism may explain why emerging countries are often caught in a middle-income trap and cannot escape it despite prolonged economic stagnation.

An obvious caveat in this paper is that we did not correct for possible biases due to endogeneity. Many of the relations between protectionism, business and political ties, and trust shown in Fig. 5.1 are contaminated by reverse causality. For example, we claimed that business networks with domestic firms lead to the protectionism of firm managers and found some evidence to support this claim. However, when their managers are protectionists, firms are more willing to transact with domestic firms and hesitate to go abroad. Therefore, the results of this paper should be viewed as showing correlation rather than causality. Future work should correct for these endogeneity biases using, for example, instrumental variable estimations. Possible 
instruments include regional and industry variables that affect the level of trust and political ties and are not impossible to obtain.

\section{References}

Alesina, Alberto, and Eliana La Ferrara. 2002. Who Trusts Others? Journal of Public Economics 85 (2): 207-234.

Algan, Yann, and Pierre Cahuc. 2014. Trust, Growth and Well-being: New Evidence and Policy Implications. Handbook of Economic Growth 2A: 49-120.

Amiti, Mary, and Jozef Konings. 2007. Trade Liberalization, Intermediate Inputs, and Productivity: Evidence from Indonesia. The American Economic Review 97 (5): 1611-1638.

Arnold, Jens Matthias, and Beata Smarzynska Javorcik. 2005. Gifted Kids or Pushy Parents? Foreign Acquisitions and Plant Performance in Indonesia. Journal of International Economics 79 (1): $42-53$.

Beugelsdijk, Sjoerd, and Sjak Smulders. 2004. Bridging and Bonding Social Capital: Which Type Is Good for Growth? In The Cultural Diversity of European Unity: Findings, Explanations and Reflections from the European Values Study, ed. Wilhelmus A. Arts, Jacques A. Hagenaars, and Loek Halman, 147-185. Brill Academic Publishing.

Blalock, Garrick, and Paul Gertler. 2004. Learning from Exporting Revisited in a Less Developed Setting. Journal of Development Economics 75 (2): 397-416.

Blalock, Garrick, and Paul Gertler. 2008. Welfare Gains from Foreign Direct Investment through Technology Transfer to Local Suppliers. Journal of International Economics 74 (2): 402-421.

Borensztein, Eduardo, Jose De Gregorio, and Jong-Wha Lee. 1998. How Does Foreign Direct Investment Affect Economic Growth? Journal of International Economics 45 (1): 115-135.

Burt, Ronald S. 1992. Structural Holes: The Social Structure of Competition. Cambridge: Harvard University Press.

Burt, Ronald S. 2004. Structural Holes and Good Ideas. American Journal of Sociology 110 (2): 349-399.

Durlauf, Steven N., and Marcel Fafchamps. 2005. Social Capital. Handbook of Economic Growth 1: 1639-1699. https://doi.org/10.1016/s1574-0684(05)01026-9.

Ermisch, John, and Diego Gambetta. 2010. Do Strong Family Ties Inhibit Trust? Journal of Economic Behavior \& Organization 75 (3): 365-376.

Fafchamps, Marcel. 2006. Development and Social Capital. The Journal of Development Studies 42 (7): 1180-1198.

Gennaioli, N., R. La Porta, F. Lopez-de-Silanes, and A. Shleifer. 2013. Human Capital and Regional Development. The Quarterly Journal of Economics 128 (1): 105-164. https://doi.org/10.1093/ qje/qjs050.

Granovetter, Mark S. 1973. The Strength of Weak Ties. American Journal of Sociology 78 (6): $1360-1380$.

Granovetter, Mark S. 2005. The Impact of Social Structure on Economic Outcomes. Journal of Economic Perspectives 19 (1): 33-50.

Javorcik, Beata Smarzynska. 2004. Does Foreign Direct Investment Increase the Productivity of Domestic Firms? In Search of Spillovers through Backward Linkages. American Economic Review 94 (3): 605-627.

Keller, Wolfgang. 2004. International Technology Diffusion. Journal of Economic Literature 42 (3): 752-782.

Knack, Stephen, and Philip Keefer. 1997. Does Social Capital Have an Economic Payoff? A CrossCountry Investigation. The Quarterly Journal of Economics 112 (4): 1251-1288. 
Martins, Pedro S., and Yong Yang. 2009. The Impact of Exporting on Firm Productivity: A Meta-Analysis of the Learning-by-Exporting Hypothesis. Review of World Economics 145 (3): 431-445.

Melitz, Marc J. 2003. The Impact of Trade on Intra-industry Reallocations and Aggregate Industry Productivity. Econometrica 71 (6): 1695-1725.

Naoi, Megumi, and Ikuo Kume. 2011. Explaining Mass Support for Agricultural Protectionism: Evidence from a Survey Experiment During the Global Recession. International Organization 65 (04): 771-795.

Nunn, Nathan, and Leonard Wantchekon. 2011. The Slave Trade and the Origins of Mistrust in Africa. American Economic Review 101 (7): 3221-3252. https://doi.org/10.1257/aer.101.7.3221.

OECD. 2012. OECD Economic Surveys: Indonesia 2012. Paris: OECD Publishing.

Olson, Mancur. 1984. The Rise and Decline of Nations: Economic Growth, Stagflation, and Social Rigidities. New Haven: Yale University Press.

Phelps, Corey C. 2010. A Longitudinal Study of the Influence of Alliance Network Structure and Composition on Firm Exploratory Innovation. Academy of Management Journal 53 (4): 890-913.

Rost, Katja. 2011. The Strength of Strong Ties in the Creation of Innovation. Research Policy 40 (4): 588-604.

Salomon, Robert M., and J. Myles Shaver. 2005. Learning by Exporting: New Insights from Examining Firm Innovation. Journal of Economics \& Management Strategy 14(2): 431-460.

Satyanath, Shanker, Nico Voigtländer, and Hans-Joachim Voth. 2013. Bowling for Fascism: Social Capital and the Rise of the Nazi Party in Weimar Germany, 1919-33. National Bureau of Economic Research.

Takii, Sadayuki. 2005. Productivity Spillovers and Characteristics of Foreign Multinational Plants in Indonesian Manufacturing 1990-1995. Journal of Development Economics 76 (2): 521-542.

Todo, Yasuyuki. 2011. Quantitative Evaluation of Determinants of Export and FDI: Firm-Level Evidence from Japan. The World Economy 34 (3): 355-381.

Todo, Yasuyuki, and Koji Miyamoto. 2006. Knowledge Spillovers from Foreign Direct Investment and the Role of R\&D Activities: Evidence from Indonesia. Economic Development and Cultural Change 55 (1): 173-200.

Todo, Yasuyuki, Weiying Zhang, and Li-An Zhou. 2011. Intra-Industry Knowledge Spillovers from Foreign Direct Investment in R\&D: Evidence from a Chinese Science Park. Review of Development Economics 15 (3): 569-585.

Todo, Yasuyuki, Petr Matous, and Hiroyasu Inoue. 2016. The Strength of Long Ties and the Weakness of Strong Ties: Knowledge Diffusion Through Supply Chain Networks. Research Policy 45 (9): 1890-1906.

Tomiura, Eiichi, Banri Ito, Hiroshi Mukunoki, and Ryuhei Wakasugi. 2013. Endowment Effect and Trade Policy Preferences: Evidence from a Survey on Individuals. RIETI Discussion Paper Series 13-E-009. Research Institute of Economy, Trade and Industry. 
Open Access This chapter is licensed under the terms of the Creative Commons AttributionNonCommercial-NoDerivatives 4.0 International License (http://creativecommons.org/licenses/bync-nd/4.0/), which permits any noncommercial use, sharing, distribution and reproduction in any medium or format, as long as you give appropriate credit to the original author(s) and the source, provide a link to the Creative Commons license and indicate if you modified the licensed material. You do not have permission under this license to share adapted material derived from this chapter or parts of it.

The images or other third party material in this chapter are included in the chapter's Creative Commons license, unless indicated otherwise in a credit line to the material. If material is not included in the chapter's Creative Commons license and your intended use is not permitted by statutory regulation or exceeds the permitted use, you will need to obtain permission directly from the copyright holder.

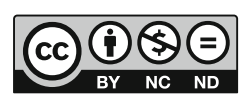

